Lee, M., Harris, K. \& Trowbridge, H. (1964). F. Nutr. 84, I 36.

Ludwig, A., Weis, J. \& Korte, F. (1964). Life Sci. 3, 123.

Marth, E. H. (1965). Residue Rev. 9, I.

Mills, P. A. (1963). F. Ass. off. agric. Chem. 46, 672.

Moore, N. W. \& Walker, C. H. (1964). Nature, Lond., 201, 1072.

Ortelee, M. F. (1958). Archs ind. Hlth, 18, 433.

Phillips, W. E. J. (1963). Can. F. Biochem. Physiol. 41, 1793.

Phillips, W. E. J. \& Hidiroglou, M. (1965). F. agric. Fd Chem. 13, 254.

Poonawall, N. H. \& Korte. (1964). Life Sci. 3, 1497.

Robinson, J., Richardson, A., Hunter, C. G., Crabtree, A. \& Rees, H. J. (1965). Br. F. ind. Med. $22,220$.

Rudd, R. L. (1964). Pesticides and the Living Landscape. Madison, Wis. : University of Wisconsin Press.

Schmittle, S. C., Edwards, H. M. \& Morris, D. (1958). F. Am. vet. med. Ass. 132, 2 16.

Wannop, C. C. \& Chubb, L. G. (196I). Vet. Rec. 73, 586.

Wootton, J. C. \& Alexander, J. C. (1959). F. Ass. off. agric. Chem. 42, I4I.

Wootton, J. C., Artman, N. \& Alexander, J. C. (1962). F. Ass. off. agric. Chem. 45, 739.

Wootton, J. C. \& Couchene, W. L. (1964). F. agric. Fa Chem. 12, 94.

\title{
The action of chemical improvers on the lipids of flour
}

\author{
By N. W. R. Daniels, Spillers Limited, Technological Research Station, Cambridge
}

\section{Introduction}

Although lipids comprise no more than $1-2 \%$ of white ( $70 \%$ extraction) flour, the nutritional significance of the flour lipids has received much attention in recent years on account of their relatively high content of essential fatty acids (EFA). Though direct evidence concerning human requirements for these factors is scanty, it has been said that EFA deficiency in the human diet may contribute towards atheroclerosis and coronary thrombosis. Moreover, the readiness with which these polyunsaturated fatty acids may be oxidized led to the suggestion that oxidative treatment of flour might seriously impair its nutritive value in the human diet (Sinclair, I956). It was this latter possibility that prompted workers in both this country and America to examine the lipids of flour with the object of evaluating quantitatively any changes that may occur in the EFA content as a result of chemical treatment.

Fisher, Ritchie \& Coppock (1958a,b) examined the effect of the improvers, chlorine dioxide, potassium bromate, ascorbic acid, ammonium persulphate, and the pigment bleach, benzoyl peroxide, on the lipids of flour, dough and bread at treatment levels mostly twice and twenty times those currently used with present-day white flours. In no instance was it possible to demonstrate a significant change in the content of EFA as a result of the use of oxidative improvers. These results were confirmed by Gilles, Anker, Wheeler \& Andrews (1958) who included infrared spectrophotometry in their examination. The possibility that contamination of chlorine dioxide with chlorine gas may cause significant EFA destruction in bread-making flours was later investigated (Coppock, N.W.R. Daniels \& Russell-Eggitt, I96o) using gas-liquid chromatography as a more direct measure of fatty acid composition than the alkaline isomerization method used by previous workers. Whereas contamination of chlorine dioxide with up to $30 \%$ chlorine gas was without effect on EFA, the use of increasing levels of treatment with pure chlorine gas (a treatment used in the production of certain speciality flours) brought about some loss of EFA. At the 
highest levels of treatment, gas-liquid chromatography showed the presence of a new peak which was tentatively identified as methyl dichlorostearate derived from dichlorostearic acid present as a minor constituent. It was also noted that at the higher levels of treatment with pure chlorine dioxide, although little change was observed in the EFA content of freshly treated flour, considerable destruction of all unsaturated fatty acids was found after prolonged storage. It is work arising from these last two observations that will be considered here in more detail.

\section{Effect of chlorine dioxide treatment on EFA}

Analysis by gas-liquid chromatography of fatty acid methyl esters from flour freshly treated with $28 \mathrm{ppm}$ chlorine dioxide ( $\mathrm{X}_{\mathrm{I}}$ level, twice that used at present) is shown in Table I together with the analysis of the same flour 39 days after treatment. On storage there was a slight fall in linoleic acid content from $63.4 \%$ to $56.4 \%$.

Table 2 shows the effect of similar storage times on the fatty acids of flour heavily treated with chlorine dioxide at the XIo level. Analysis of the freshly treated flour, 5 days old, showed no significant loss of linoleic acid compared with the untreated flour, although a fall was noted in the linolenic acid content. After storage for 39 days, however, severe loss of all unsaturated acids was found, the EFA content falling from

Table I. Gas-liquid chromatographic analysis of lipids of flour treated at $X_{\mathrm{I}}$ level (fatty acids expressed as \% of mixed methyl esters)

\begin{tabular}{|c|c|c|c|c|c|c|}
\hline & & & & treated wi & $8 \mathrm{ppn}$ & $O_{2}$ for: \\
\hline & & $\begin{array}{l}\text { ed flour } \\
6)\end{array}$ & & lays & & $\begin{array}{l}\text { days } \\
\text { (0) }\end{array}$ \\
\hline Acid & $\%$ & $\begin{array}{l}\text { Standard } \\
\text { deviation }\end{array}$ & $\%$ & $\begin{array}{l}\text { Standard } \\
\text { deviation }\end{array}$ & $\%$ & $\begin{array}{l}\text { Standard } \\
\text { deviation }\end{array}$ \\
\hline Palmitic & 15.4 & 0.9 & $16 \cdot 3$ & $1 \cdot 7$ & $21 \cdot 3$ & 0.7 \\
\hline Oleic & $\begin{array}{l}16 \cdot 2 \\
16\end{array}$ & $\mathrm{I} \cdot \mathrm{O}$ & $16 \cdot 3$ & $\begin{array}{l}1 \\
1.4\end{array}$ & $17 \cdot 1$ & 0.8 \\
\hline Linoleic & $63 \cdot 2$ & $I \cdot I$ & $63 \cdot 4$ & I. 8 & $5^{6 \cdot 4}$ & $\mathrm{r} \cdot 6$ \\
\hline Linolenic & $5 \cdot 3$ & 0.4 & 3.8 & 0.6 & $3 \cdot 7$ & 0.2 \\
\hline Undetected & 0.0 & & 0.0 & & $\mathrm{I} \cdot 5$ & \\
\hline
\end{tabular}

Figures in parentheses are the numbers of chromatograms.

Table 2. Gas-liquid chromatographic analysis of lipids of flour treated at XIo level (fatty acids expressed as \% of mixed methyl esters)

\begin{tabular}{|c|c|c|c|c|}
\hline & \multicolumn{4}{|c|}{ Flour treated with $280 \mathrm{ppm} \mathrm{ClO}_{2}$ for: } \\
\hline Acid & \multicolumn{2}{|c|}{$\begin{array}{l}5 \text { days } \\
\text { (6) }\end{array}$} & \multicolumn{2}{|c|}{$\begin{array}{l}39 \text { days } \\
(5)\end{array}$} \\
\hline Palmitic & $20 \cdot 3$ & $\mathrm{I} \cdot 8$ & $19 \cdot 8$ & $3 \cdot 6$ \\
\hline Oleic & I6.8 & 0.9 & $7 \cdot 5$ & 0.6 \\
\hline Linoleic & $60 \cdot 1$ & $2 \cdot 1$ & 4.5 & $I \cdot 5$ \\
\hline Linolenic & $2 \cdot 6$ & 0.5 & nil & - \\
\hline Undetected & 0.2 & & $58 \cdot 2$ & \\
\hline
\end{tabular}

Figures in parentheses are the numbers of chromatograms. 
$68.5 \%$ to $14.5 \%$ and giving rise to $58.2 \%$ of undetectable fatty acid products (N. W. R. Daniels, Russell-Eggitt \& Coppock, I960). Similar results were obtained concurrently with this work by D. G. H. Daniels (r960). However, flour treated with $120 \mathrm{ppm}$ chlorine dioxide (a level far in excess of that in any commercial treatment) was found to be stable during storage up to ${ }_{5}$ weeks after treatment (D. G. H. Daniels, ig60).

Since severe treatment ( $\mathrm{X}_{\text {Io }}$ level) is known to destroy completely the vitamin $\mathrm{E}$ of flour (Frazer, Hickman, Sammons \& Sharratt, 1956), it was suspected that the changes observed were due to air oxidation of the unsaturated lipids. In order to examine this possibility a sample of flour was treated with $280 \mathrm{ppm}$ chlorine dioxide and divided into two samples 5 days after treatment. One sample was stored in a closed tin in the presence of air; the other in a sealed vacuum desiccator in which the air had been replaced with oxygen-free nitrogen by repeated evacuation and fill-

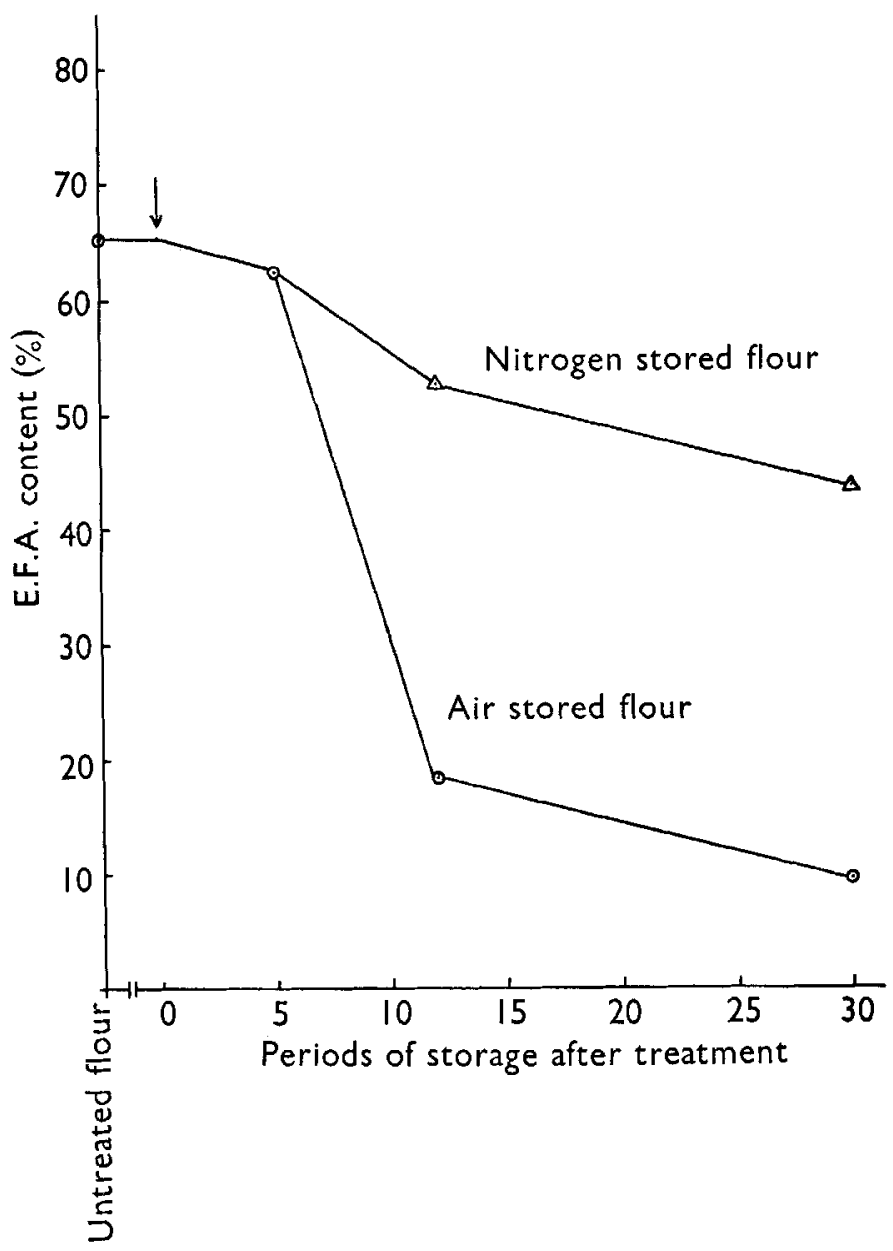

Fig. I. Essential fatty acid content (gas-liquid chromatographic analysis) of fatty acids of flours stored in air $(O-O)$ and in nitrogen $(\triangle-\triangle)$. Flour was treated with $280 \mathrm{ppm}$ chlorine dioxide at $\downarrow$ and stored for the number of days indicated. (From N. W. R. Daniels et al. 1960.) 
ing. Samples were taken from each flour during storage for 30 days and the EFA content of the flour lipid was determined by gas-liquid chromatography.

Fig. I shows the EFA content of the flour fatty acids plotted against storage time for the two conditions of storage. Exclusion of air resulted in a marked reduction in the rate of destruction of EFA compared with the rapid destruction in the airstored flour. A possible explanation of the small, consistent fall in the EFA of flour stored in nitrogen may be that at each sampling a small amount of air was retained by the flour in spite of the evacuation technique employed. It would appear from these results that the rapid and extensive loss of EFA in the air-stored sample was most likely caused by air oxidation of the unsaturated lipids rather than by their destruction through any direct action of chlorine dioxide during flour treatment. The occurrence of air oxidation in the heavily treated flour is thus in agreement with the work of Moran, Pace \& McDermott (1954) and Moore, Sharman \& Ward (I957) who demonstrated a loss of tocopherols after treatment, and with the findings of Frazer et al. (1956) referred to earlier. Flour thus denuded of its antioxidants would be expected to display rapid autoxidation of its unsaturated lipids, as was found in these experiments, but at the very much lower levels of treatment now used it would appear that adequate amounts of antioxidant remain in the flour to ensure that there is little danger of loss of EFA through air oxidation during storage.

\section{Studies on the lipid of chlorine-treated cake flour}

As mentioned earlier, treatment of flour with high levels of chlorine, such as is used in the production of speciality cake flour, leads to the destruction of part of the EFA present in the untreated flour (Coppock et al. 1960). To investigate the effect of variation in chlorine treatment on the lipids of flour, cake flour was treated with three different levels of chlorine up to a maximum of $0.2 \%(w / w)$, a level much higher than that used normally in the production of speciality cake flours. Gas-liquid chromatographic analyses of the component fatty acids are shown in Table 3 illustrating that chlorination of the unsaturated fatty acids leads to a rise in the percentage of undetectable lipid derivatives which is approximately proportional to the quantity of chlorine employed. At the highest level of treatment the unsaturated fatty acids were reduced to less than half their original values, oleic acid being affected equally with the polyunsaturated linoleic and linolenic acids.

To obtain more information on the nature of the normally undetected products formed at the expense of the unsaturated fatty acids, the esters obtained from the lipid from heavily chlorinated cake flour were analysed under gas-liquid chromato-

Table 3. Effect of different levels of chlorine treatment of cake flour on the fatty acid contents of the lipids (fatty acids as \% of mixed methyl esters)

$\begin{array}{cccccc}\begin{array}{c}\text { Chlorine level } \\ (\%, w / w)\end{array} & \text { Palmitic } & \text { Oleic* } & \text { Linoleic } & \text { Linolenic } & \text { Undetected } \\ \text { None } & 18.9 & 12.5 & 64.4 & 4.3 & \text { Nil } \\ 0.04 & 19.2 & 12.8 & 57.6 & 4.8 & 5.6 \\ 0.12 & 22.5 & 10.0 & 41.4 & 3.2 & 22.9 \\ 0.20 & 21.3 & 4.5 & 25.3 & 0.9 & 48.0\end{array}$

*Including approximately $\mathrm{r} \%$ of stearic acid not separated on the chromatogram. 
graphy conditions specially chosen to facilitate their detection (N. W. R. Daniels, Frape, Russell-Eggitt \& Coppock, 1963). The chromatogram obtained is compared with that from untreated flour lipid in Fig. 2 and the comparative percentage values are given in Table 4 . The results show the presence of a number of unidentified compounds not present in the untreated control. However, although treatment reduced the unsaturated fatty acids by $60 \%$, only $16 \%$ of new material was detected on the chromatogram.

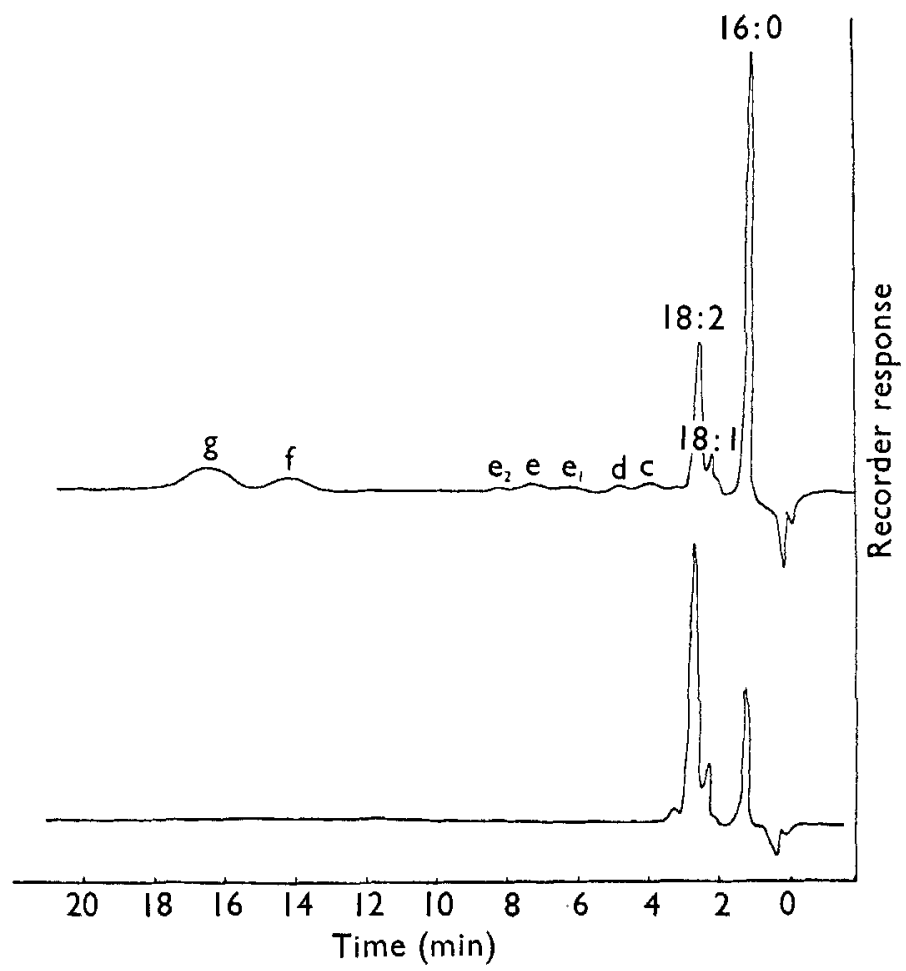

Fig. 2. Gas-liquid chromatograms of methylated acids from chlorine-treated cake flour (upper curve, recorder sensitivity increased three times) and untreated cake flour. $g, f, e_{2}, e, e_{1}, d, c$, unidentified components. (From N. W. R. Daniels et al. 1963 ).

Table 4. Fatty acid composition (expressed as \% of mixed methyl esters) of the lipid from untreated and chlorine-treated cake flour

\begin{tabular}{|c|c|c|}
\hline Acid & Untreated & $\begin{array}{l}\text { Chlorine-treated } \\
\left(0.2 \% \mathrm{Cl}_{2}, \mathrm{w} / \mathrm{w}\right)\end{array}$ \\
\hline Palmitic: & 19.7 & 19.5 \\
\hline Stearic & $I \cdot 2$ & $1 \cdot 0$ \\
\hline Oleic & I 3.1 & $4 \cdot 2$ \\
\hline Linoleic & $61 \cdot 4$ & $12 \cdot 9$ \\
\hline Linolenic & $4 \cdot 7$ & $1 \cdot 5$ \\
\hline Unknown: c & - & $1 \cdot 6$ \\
\hline d & - & $I \cdot I$ \\
\hline$e_{1}$ & - & 0.6 \\
\hline e & - & $2 \cdot 0$ \\
\hline$e_{2}$ & - & $1 \cdot 3$ \\
\hline$f$ & - & $3 \cdot 1$ \\
\hline $\mathbf{g}$ & - & $6 \cdot 6$ \\
\hline
\end{tabular}


For comparison with the unknown compounds from flour oil, oleic acid was chlorinated and methylated. It was found that the major methylated derivative present in the reaction products had a retention time closely similar to that of the unidentified compound $\mathrm{g}$ found in the lipid from chlorinated flour, suggesting oleic acid as the precursor of compound $g$ in flour lipid.

\section{Identification of compound $g$}

Since this material was present in only a trace amount in cake flour treated with chlorine at the highest level, considerable concentration was necessary before chemical analysis could be undertaken. Molecular distillation of the methyl esters from cake flour lipid and from chlorinated oleic acid succeeded in raising the concentration of compound $\mathrm{g}$ in these samples to a level at which preparative gasliquid chromatography could be used to achieve final separation of the pure material (N. W. R. Daniels, Russell-Eggitt \& Coppock, I962).

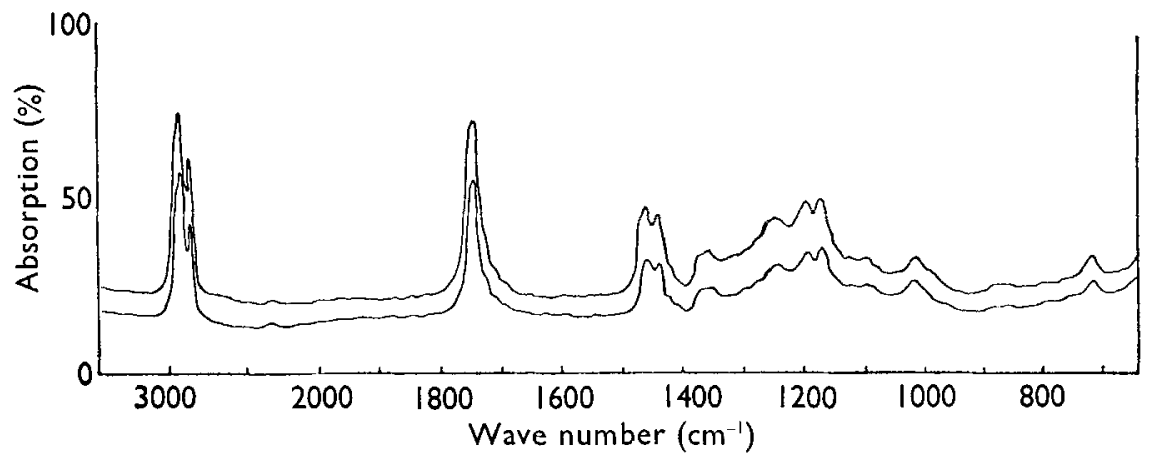

Fig. 3. Infrared spectrums of highly purified compound $\mathrm{g}$ from chlorinated oleic acid (upper curve) and chlorine-treated cake flour (lower curve). Wave number scale condensed above 2000 (factor $=$ four times). (From N. W. R. Daniels et al. 1963.)

The infrared spectrums of these two methyl ester samples are shown in Fig. 3. The identity of the two spectrums provided strong evidence that the unidentified compound $\mathrm{g}$ from the lipid of chlorinated flour was the same material as that produced by the chlorination of oleic acid. Further examination of these spectrums in the far infrared showed that both samples exhibited strong absorption at $645 \mathrm{~cm}^{-1}$, in the region characteristic of carbon chlorine bonding. It was also noted that there was no absorption in the infrared region just above $3000 \mathrm{~cm}^{-1}$ indicating the absence of unsaturation. These results suggested that compound $\mathrm{g}$ was derived from dichlorostearic acid formed by the direct addition of chlorine across the single unsaturated bond of oleic acid in cake flour lipid. This conclusion was supported by the results of molecular weight determinations and combustion analysis which gave $\mathrm{C}, 62 \cdot 6$; $\mathrm{H}$, I0.I ; O, IO.I; Cl, I7.2\% (methyl dichlorostearate, $\mathrm{C}_{19} \mathrm{H}_{36} \mathrm{O}_{2} \mathrm{Cl}_{2}$, requires $\mathrm{C}$, $62 . \mathrm{I} ; \mathrm{H}, 9.8 ; \mathrm{O}, 8.8 ; \mathrm{Cl}, \mathrm{I9} \cdot 3 \%$ ) and a molecular weight between 350 and 430 (required: $367 \cdot 5$ ).

\section{Toxicological studies on the lipid from chlorine-treated cake flour}

Since it had been shown that chlorine treatment of cake flour resulted in considerable changes in the flour lipid, it was of importance to investigate what effect, 
if any, the chlorinated lipid would have in a biological feeding experiment. Albino rats were chosen as the experimental animals and were fed ad lib. on a basal diet of high nutritive value supplemented in one instance with extracted flour oil to a level approximately equal to that which would be eaten should the diet consist solely of cake flour (designated XI level). This appeared to give a reasonable factor of safety in relating these experiments to the human toxicological problem since the amount of chlorinated flour consumed in all cake products is probably not more than I. $5 \%$ of the total flour consumption (Ministry of Agriculture, Fisheries and Food: Food Standards Committee, 1960). Oil extracted from flour treated with the highest level of chlorine $(0.2 \%)$ was used in the test $\operatorname{diet}\left(\mathrm{T}_{\mathrm{I}}\right)$, the control diet (UI) being supplemented with an equal quantity of oil extracted from untreated cake flour. Another group of rats was fed on a diet supplemented with five times these quantities of flour oil $\left(\mathrm{X}_{5}\right.$ level, diets $\mathrm{T}_{5}$ and $\left.\mathrm{U}_{5}\right)$ as an extremely severe test of toxicity far beyond any practical intake in human nutrition.

In the initial experiment fifteen weanling rats from the breeding colony were allotted at random to three blocks of five pens each. For each diet, basal, UI, U 5 , TI and $\mathrm{T}_{5}$, there were three replicates, two male and one female. Since there were no general toxicity signs in the early weeks, the experiment was continued through a number of generations. The growth curves for male and female rats are given separately in Fig. 4 and show little adverse effect of the chlorinated lipids on growth

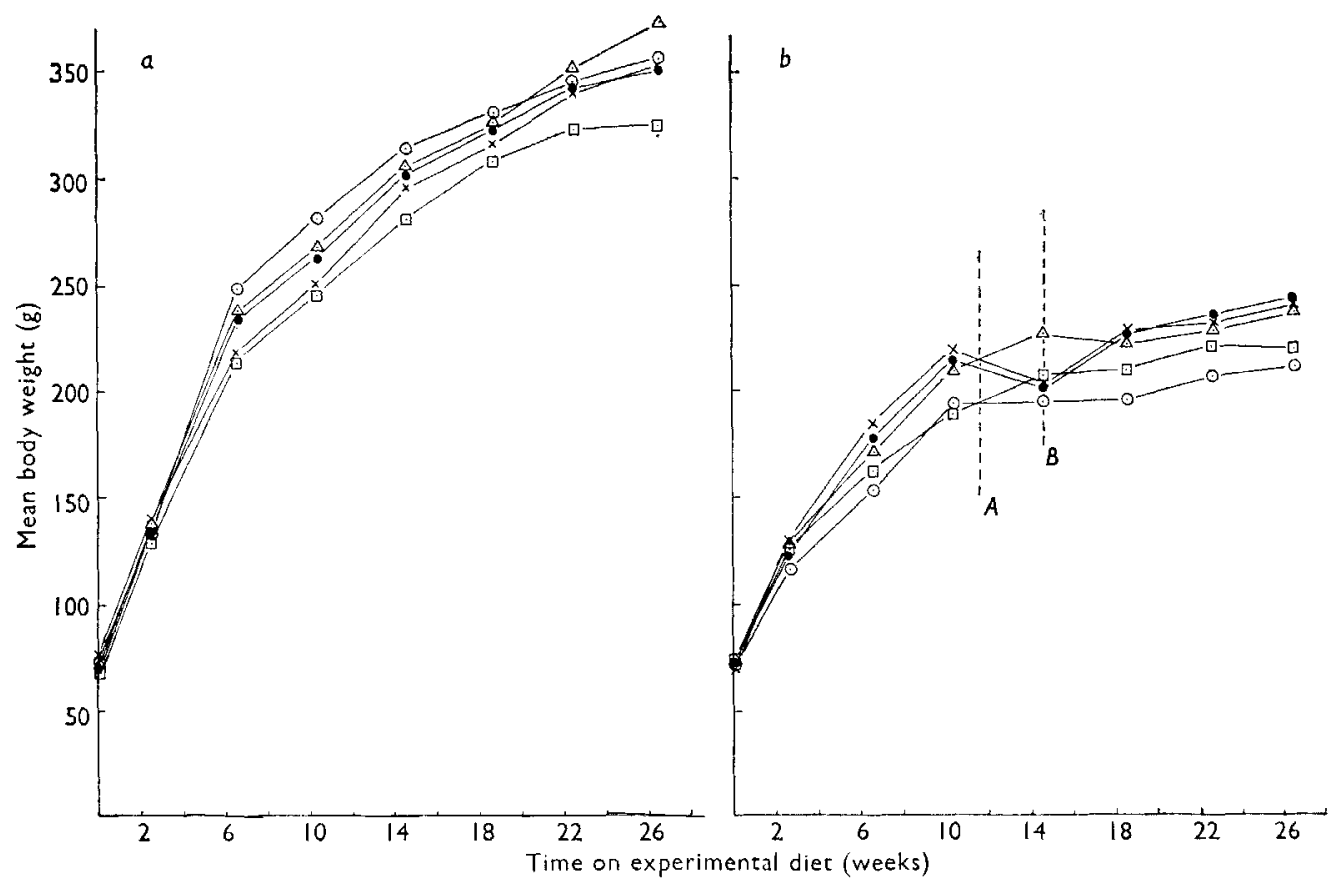

Fig. 4. Growth curves of first generation rats receiving experimental diets: - - basal; $0-0$, diet $\mathrm{U}_{\mathrm{I}} ; \times-\times$, diet $\mathrm{U}_{5} ; \Delta-\Delta \operatorname{diet} \mathrm{T}_{\mathrm{I}} ; \square-\square \operatorname{diet} \mathrm{T}_{5} . a$, male rats; $b$, female rats; $A$, litters born; $B$, litters weaned. (From N. W. R. Daniels et al. 1963.) 
characteristics. Even rats receiving diet $\mathrm{T}_{5}$ showed no marked signs after 6 months on the diet, although it was thought that the coats of male rats on this diet were a little thin and slightly rougher than those of rats on the control diets. No other pathological changes were observed, either internally or externally.

Table 5. Weaning weights of second generation rats in groups given diets supplemented with oil from untreated or chlorinated flour (see p. 57)

$\begin{array}{ccc}\text { Diet } & \begin{array}{c}\text { No. of } \\ \text { offspring }\end{array} & \begin{array}{c}\text { Mean weight } \\ \text { at weaning }(\mathrm{g})\end{array} \\ \text { Basal } & \text { I3 } & 28 \cdot 2 \\ \mathrm{U}_{1} & \text { I } & 30 \cdot 4 \\ \mathrm{U}_{5} & 9 & 3 \mathrm{I} \cdot 2 \\ \mathrm{Tr}_{\mathrm{T}} & \mathbf{1 2} & 29 \cdot 6 \\ \mathrm{~T}_{5} & 9 & 20.6\end{array}$

At $3 \frac{1}{2}$ months of age, rats were mated within each treatment and produced litters, of which the numbers and weaning weights are shown in Table 5 . From this it will be seen that, although the chlorinated lipid at the $\mathrm{X}_{\mathrm{I}}$ level ( $\mathrm{T}_{\mathrm{I}}$ ) had no effect on weaning weight, the offspring at the $\mathrm{X}_{5}$ level $\left(\mathrm{T}_{5}\right)$ were significantly lighter in weight owing, it was thought, to a deficiency in milk production on the part of the mother. Second generation rats (two male and two female) from each litter were weaned on to the same diet as that received by their parents. The growth of these rats was followed and, as found previously, inclusion of chlorinated lipid even at the highest level was without effect on the growth and development after weaning.

The females (two from each diet) were mated at 4 months with males from the breeding colony. To obtain more information about the effect of chlorinated lipid on lactation, the litters were divided at birth so that one half-litter remained with the mother and the other half-litter was put with a foster mother receiving a different diet. By dividing the litters in this way it was possible to separate the effect of genetical background plus environment during gestation from that of milk production under the different treatments. It was concluded from this experiment that it was in fact the diet received by the nursing rat that influenced weaning weight rather than the diet on which the parent rat had been fed (N. W. R. Daniels et al. 1963).

Finally, the effect of replacing diet $\mathrm{T}_{5}$ with the basal diet at $4 \frac{1}{2}$ weeks from weaning was studied in order to observe any cumulative effect of chlorinated lipid on the breeding performance of the rat. Rats from the third generation were fed on basal, $\mathrm{U}_{5}$ and $\mathrm{T}_{5}$ diets since the $\mathrm{X}_{\mathrm{I}}$ diet had consistently failed to show any effect at this intake level of chlorinated lipid, and no beneficial effect was noticed when this diet was replaced by the basal diet. Rats were mated at 7 weeks of age and produced good-sized litters on all diets. The weaning weights of the fourth generation rats are given in Table 6 and show that there was no significant difference between weaning weights in any group in spite of the influence of chlorinated lipid in the first $4 \frac{1}{2}$ weeks after weaning in one group. This lack of cumulative effect of chlorinated lipid was confirmed by gas-liquid chromatography analysis of body fat from rats fed for 5 months on diets $\mathrm{U}_{5}$ and $\mathrm{T}_{5}$. Though a trace amount of dichlorostearic acid was 
Table 6. Weaning weights of fourth generation rats in groups given diets supplemented with oil from untreated or chlorinated flour (see p. 57)

\begin{tabular}{|c|c|c|c|}
\hline \multicolumn{2}{|c|}{ Diet of parent rats } & \multirow[b]{2}{*}{$\begin{array}{l}\text { No. in } \\
\text { litter }\end{array}$} & \multirow{2}{*}{$\begin{array}{l}\text { Mean weaning } \\
\text { weight of rats } \\
\text { (g) }\end{array}$} \\
\hline $\begin{array}{l}\text { Up to } 4 \frac{1}{2} \text { weeks } \\
\text { from weaning }\end{array}$ & $\begin{array}{l}\text { After } 4 \frac{1}{2} \text { weeks } \\
\text { from weaning }\end{array}$ & & \\
\hline Basal & Basal & 8 & $24 \cdot 8$ \\
\hline $\mathrm{U}_{5}$ & $\mathrm{U}_{5}$ & 10 & 25.7 \\
\hline $\mathrm{U}_{5}$ & $\mathrm{U}_{5}$ & 8 & $32 \cdot 4$ \\
\hline $\mathrm{T}_{5}$ & Basal & 9 & $25 \cdot 2$ \\
\hline$T_{5}$ & Basal & 9 & $26 \cdot 3$ \\
\hline
\end{tabular}

detected with difficulty in the depot fat of the rat given the chlorinated lipid, the amount present was many times less than that present in the dietary lipid.

\section{Discussion}

The significance of polyunsaturated acids in relation to coronary heart disease is still controversial (see Howard \& Gresham, 1965) and recent work from the Harvard Department of Nutrition now suggests that myristic acid is an important dietary variable governing serum cholesterol levels in man (Anonymous, 1965). However, a reasonable substitution of polyunsaturated for saturated fat has been recommended in the human diet (American Heart Association, 1961) and the EFA content of dietary fat is still of considerable interest in relation to the aetiology of vascular disease.

The possibility that the methods of oxidative improvement used now in the treatment of white bread flour may adversely affect its nutritive value by destroying a significant proportion of EFA has not been confirmed by the investigations of a number of workers using several methods of analysis. It would appear that chlorine dioxide has little direct effect on the flour lipids even at levels considerably in excess of those used commercially. However, these impracticably high levels of treatment cause some loss of flour antioxidants thus leading to subsequent atmospheric oxidation of the unsaturated lipids.

The stability of flour lipids to normal low levels of oxidative improvers, originally considered mainly in relation to the major essential fatty acid of flour (linoleic acid, 60-64\%), applies equally to the minor polyunsaturated acid, linolenic acid $(4-5 \%)$. This stability may be of greater importance than previously suspected, in view of the recent observations regarding the function of linolenic acid as a factor capable of reducing blood platelet adhesiveness (and thereby the tendency to thrombosis) in atherosclerosis (Owren, Hellem \& Ödegaard, 1964).

Detailed examination of the effects of high levels of chlorine treatment on the component fatty acids of cake flour lipid revealed the presence of a number of unidentified compounds. One of the minor constituents proved to be dichlorostearic acid. Although chlorine treatment results in some loss of EFA, the contribution to the diet made by flours treated at the highest levels studied is extremely small, being considerably less than the figure of $1.5 \%$ given as the percentage cake flour in the 25 (I) 5 
overall national flour consumption, which in turn is only about one-fifth to onequarter of the total dietary intake.

Moreover, in view of the quantities of cake flour consumed, there is clearly little or no toxicological hazard. Comprehensive feeding experiments with rats over four generations showed that only at extremely high intakes of heavily treated lipid (intakes far beyond practical possibility) can any biological effect be observed (lactation impairment) and, even at these high levels, there was little tendency for the chlorinated lipid to accumulate in the depot fats.

It may be concluded from these results that the use of permitted oxidizing improvers at practicable levels in flour milling does not reduce the important contribution made by bread flour to dietary EFA in this country. The lipid of cake flour chlorinated at the highest levels ever used commercially would appear to be non-toxic at levels of dietary intake far higher than can be attained in practice in human nutrition.

\section{REFERENCES}

American Heart Association (196I). Circulation, 23, 133.

Anonymous. (1965). Fd Drug Res. no. 42, p. I.

Coppock, J. B. M., Daniels, N. W. R. \& Russell-Eggitt, P. W. (1960). Chemy Ind. p. I7.

Daniels, D. G. H. (1960). F. Sci. Fd Agric. 11, 664.

Daniels, N. W. R., Frape, D. L., Russell-Eggitt, P. W. \& Coppock, J. B. M. (1963). F. Sci. Fd Agric. I4, 883 .

Daniels, N. W. R., Russell-Eggitt, P. W. \& Coppock, J. B. M. (1960). F. Sci. Fd Agric. Ir, 658.

Daniels, N. W. R., Russell-Eggitt, P. W. \& Coppock, J. B. M. (1962). Proc, int. Congr. Fd Sci. Technology. I. London, Sect. Ca.

Fisher, N., Ritchie, M. L. \& Coppock, J. B. M. (1958a). Chemy Ind. p. 720.

Fisher, N., Ritchie, M. L. \& Coppock, J. B. M. (1958b). Chemy Ind. p. 136r.

Frazer, A. C., Hickman, J. R., Sammons, H. G. \& Sharratt, M. (1956). F. Sci. Fd Agric. 7, 375.

Gilles, K. A., Anker, C. A., Wheeler, D. H. \& Andrews, J. S. (I958). Cereal Chem. 35, 374.

Howard, A. N. \& Gresham, G. A. (1965). Chemy Ind. p. 83 I.

Ministry of Agriculture, Fisheries and Food: Food Standards Committee (1960). Report on Bread and Flour, p. 54. London: HM Stationery Office.

Moore, T., Sharman, I. M. \& Ward, R. J. (1957). F. Sci. Fd Agric. 8, 97.

Moran, T., Pace, J. \& McDermott, E. E. (1954). Nature, Lond., 174, 449.

Owren, P. A., Hellem, A. J. \& Ödegaard, A. (1964). Lancet, ii, 975.

Sinclair, H. M. (1956). Lancet. i, $38 \mathrm{I}$. 